\title{
Deradicalism, Nationalism, and Media Studies: A Study within the Film Rumah Merah Putih
}

\author{
Hendra Kaprisma \\ \{kaprisma@ui.ac.id\} \\ Faculty of Humanities, Universitas Indonesia, Depok, Indonesia
}

\begin{abstract}
The study of Indonesian films that depict and portray nationalism is a compelling and thought-provoking issue to be brought to advanced discussions in current media studies. Waves of extreme radicalism happening in Indonesia has become one of the factors behind the act of various media to critique the issue stated beforehand. Among the media is the film Rumah Merah Putih. This film demonstrates love and compassion for the homeland. Within this film, there is a scene that was inspired by the incident of Johannes Adekalla who climbed a flagpole during the commemoration of the $73^{\text {rd }}$ Indonesian Independence Day at Atambua, Belu, Nusa Tenggara Timur in 2018. The context within the film becomes a strong motive in forming critiques and criticism, both artistically and aesthetically. The research question then becomes what issues are being criticized in the film and how did the film delivers its criticism to the wide audience. In line with this, the analysis of culture and society becomes a critical and crucial aspect of deconstructing and identifying the meaning of the film. Text and context analysis within the film will be studied using Sven Windhal and Denis McQuail's communication model (1982). Thus, the hidden and implicit ideology buried within the visual wrap of the film Rumah Merah Putih will be revealed and studied critically.
\end{abstract}

Keywords: deradicalism, film, ideology, media studies, nationalism.

\section{Introduction}

Popular culture is a product from industrial society which in practice has a certain marking and an observable product (culture) is produced in large quantities and sometimes assisted by technological tools while producing it, distributing it, and duplicating it in mass quantities to be easily accessed by the public [1]. One of the media of popular culture based on this research is the film. The function of a film can work unexpectedly since cinematic interventions cannot be reduced to subtle or blatant propaganda, emotional outcries, or moral didactics [2]. Besides, the film also gives influence through its visual elements that can influence or intervene in the aspect of people's lives in terms of politics, culture, and international relations.

The film "Rumah Merah Putih" is a film based on a true story that occurred on August 17, 2018. At the moment of the celebration of the Independence Day of the Republic of Indonesia, a quite crowded moment occurred in Indonesia, namely the story of Joni or Johanes Adekalla climbing a red and a white flagpole so that it could fly at Atambua, Belu Regency, East Nusa Tenggara. Although this film is inspired by the true heroic story, this film also tells the life of Belu people as a portrait of Indonesian border community life and about the love of nationalism which is depicted from the portrayal of Farel and Oscar characters who 
understand the sacred meaning of the Indonesian Red and White heritage flag. This film that directed by Ari Sihasale and Nia Zulkarnaen also acts as a medium to convey to the people of Indonesia (as an audience or audience) about the importance of fostering a sense of unity and nationalism within the Indonesian people. The purpose of the film production, which was aired to the public on June 20, 2019, was inseparable from the social reality of the Indonesian people regarding the emergence of the seeds of radicalism that sought to divide the unity of the Indonesian nation.

One of the facts that prove that radicalism emerged in Indonesia in the 2000s is known that the heartland of Central Java or Solo as the most fertile ground growth of such radicalism originated from the Darul Islam revolutionary movement [3]. The Islamic revolutionary movement aims "in the context of capitalist transformation during the New Older is helpful to explain the broader evolution of Islamic dissent against the secular state in Indonesia up to the present day." [3]. The emergence of the fact of the radicalism movement in Indonesia in the post-reform era was due to political problems that gave rise to symptoms of radical action and the fact that the population of Muslims grew very rapidly in this area [4]. The Islamic radicalism movement in Indonesia, according to Ahmad Asrori, has a variety of objectives, "Some are just fighting for the implementation of syaria at Islam without the need to establish an" Islamic state ", but there are also those who fight for the establishment of" Islamic caliphate ", the pattern of the pattern of organization also varies" [4].

Based on the introduction above, this article discusses the meaning or the message that conveys in the film titled "Rumah Merah Putih" and how the articulation of the message in this film. The meaning or message that is trying to be studied from the film "Rumah Merah Putih" (2019) is about messages about nationalism to the audience, which are specifically shown to Indonesian people who live in multicultural countries and are vulnerable to radicalism movements that try to separate the sense of unity in Indonesian society. Thus, this article examines the relationship of nationalism values which aims to provide the issue or concept of deradicalism that is displayed through the storyline, characterizations, and the background of the true story that is displayed in this film.

This article will discuss a film titled "Rumah Merah Putih" which was inspired by the real events that occurred in 2017 in Atambua, Belu, East Nusa Tenggara. The real events that occurred at that time coincided with the moment of the commemoration of the 73rd Independence Day of the Republic of Indonesia in the form of a ceremony. The warning was accompanied by an incident or heroic action carried out by Johannes Adekalla or Joni, who at that time he was climbing a pole to connect a broken rope at the flagpole of his school. This causes the RMP film inspired by the story to become corpus material in the review of this article. The issue of nationalism or the sense of unity of the homeland in Indonesia raised in the film is also used as the context of the study in this article.

The film, entitled "Rumah Merah Putih" (2019), became a medium of popular culture products that served to represent nationalism in Indonesia. The nationalism is represented through the main characters in this film, namely the character Farel played by Petrick Rumlaklak and the Oscar character played by Amori De Purivicacao in the life of Indonesia's border regions. This article aims to identify and construct the meaning that is trying to be displayed and conveyed to the audience or audience, especially the Indonesian people in the nationalism film titled "Rumah Merah Putih". 


\section{Literature Study}

The mass media that are developing nowadays are a medium that is "simply manifested from the attention given by the public to certain issues and ignoring other things or issues that give effect to the emergence of public opinion or public opinion" [5]. This causes the perception that the mass media have a strong role to convey information that has an impact on behavior change or directly changes in opinion in the community. Therefore, the agendasetting hypothesis appears, which is a way to connect the possible impact of opinion changes that are the basis of what is provided by the educational function of the mass media [5].

The mainstream approach is a utility which in its thinking assumes that the logical relationship between the way media is used and the purpose of satisfaction can be measured, which is reflected by the main feature called the 'transmission model' [5]. That causes that the intensive use of media for convenience purposes is described more as a culture than as information. To understand the experience of 'culture' with the media, then came the concept of a culturalist model of media use by McQuail which gave two cultural meanings namely a set of textual culture, products and practices consisting of media experiences of different tastes and preferences that guide individual choices among which media are available [5]. The cultural taste referred to earlier refers to certain individual attributes or preference patterns formed by the family, social class environment, education, and 'cultural capital' within each individual ([5]. The development of the 'culture of taste' will refer to an organized set of cultural artifacts that are not united by the aesthetics of any party or by the preference of class or social groups.

Based on the previous study of [5] communication model theory, the most recent study of the values of nationalism in Indonesian films in the post-reform era was a film titled "Gie" in 2005 in Indonesia. The film tells the story of Soe Hok Gie who is a legendary Indonesian student because he was an activist in the 1960s, is of Chinese ethnicity and died at the age of 27 while climbing a mountain. This film seeks to convey a new spirit of optimism for Indonesia in the post-reform era, which conveyed this message through a storyline that tells the activities of activists who tried to oppose the New Order government in the 1960s (inspired by the story written by Soe Hok Gie in his diary during his life) [1].

The film is one form of media from popular culture. The media in this context, according to Bourdieu, have the power to influence fields such as science, politics, or literature, because in the media there are "heteronomous individuals" who are people from outside but have little authority because of values in the field. These fields (1996). As for in his book entitled On Television explained about one film entitled Actes de la recherche en sciences sociales which tells about how the wrong way directly forms of democracy can play a role when the media act in calculated ways to mobilize the public. This shows that democracy directly maximizes the effects of both pressures working on the media and collective emotions [6].

The literature study used in this article on the issue of radicalism comes from Bourdieu's book entitled Key Sociologist, one of which discusses the peak of the French student radicalism movement in May 1968. One of the events was caused by the existence of 'subjective expectations' and 'objective probabilities' which are out of reach of each other (1992). Another cause of the radicalism movement based on events in France is the existence of, "The break in the circle linking 'expectation and opportunities' was an 'objective break' (which changed the situation again), which individuals affected had no hand in producing" [7]. So that the growth of radicalism is the permission of an individual to step out of a previous circle of life which actually is a trap of a game rule in the circle of life that is chosen next. So 
the literature study in analyzing the film "Rumah Merah Putih" (2019) includes readings that cover the themes of the theory of Sven Windhal and Denis McQuail's communication model (1982) related to the text and context contained in the film, films that discuss nationalism or deradicalism, namely the film "Gie" (2005), the issue of the emergence of radicalization, and one example of a radical movement that emerged in France by students in 1968.

\section{Method}

The method used to study the film "Rumah Merah Putih" is a descriptive method of comparative analysis. The descriptive analysis method is a research method to describe the facts (facts about the issues of nationalism, radicalism, and deradicalism that occurred in Indonesia in the post-reform era) whose facts are then analyzed based on the values conveyed in the film "Rumah Merah Putih". The results of the study based on the descriptive analysis method are then compared with the facts that occur in Indonesian society in the current postreform era so that this article study attempts to examine to examine the deradicalism, radicalism, and media studies in the film "Rumah Merah Putih".

\section{Text and context within the film Rumah Merah Putih}

A film which is a product of popular culture based on the explanation of McQuail \& Windahl plays a strong role in conveying information that affects the impact of changing attitudes in people's lives or directly impacting public opinion. Also, films contain a set of textual culture, products, and practices consisting of media experiences of different tastes and preferences that guide individual choices among which media are available [5]. Therefore, to prove that the definition of roles, functions, and values contained in the film titled "Rumah Merah Putih" (2019), then in this section some scenes from the Ari Sihasale will be taken from the official trailer of "Rumah Merah Putih" that published to the public via YouTube on May 21, 2019. Minutes 01:54 is a scene when a character named Farel tries to climb the Red and White flagpole because he was cheered on by one of his friends, Oscar.

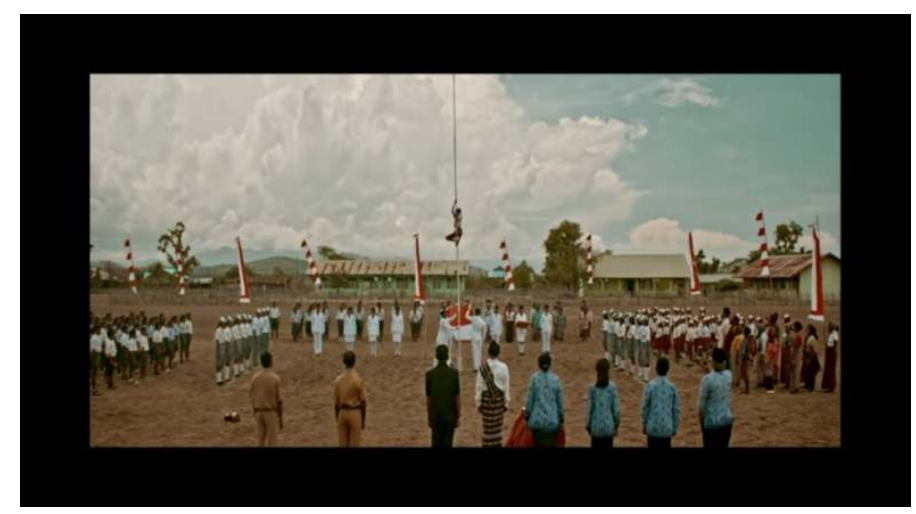

Fig. 1. Cut scenes at 01:54 in the film Rumah Merah Putih" 


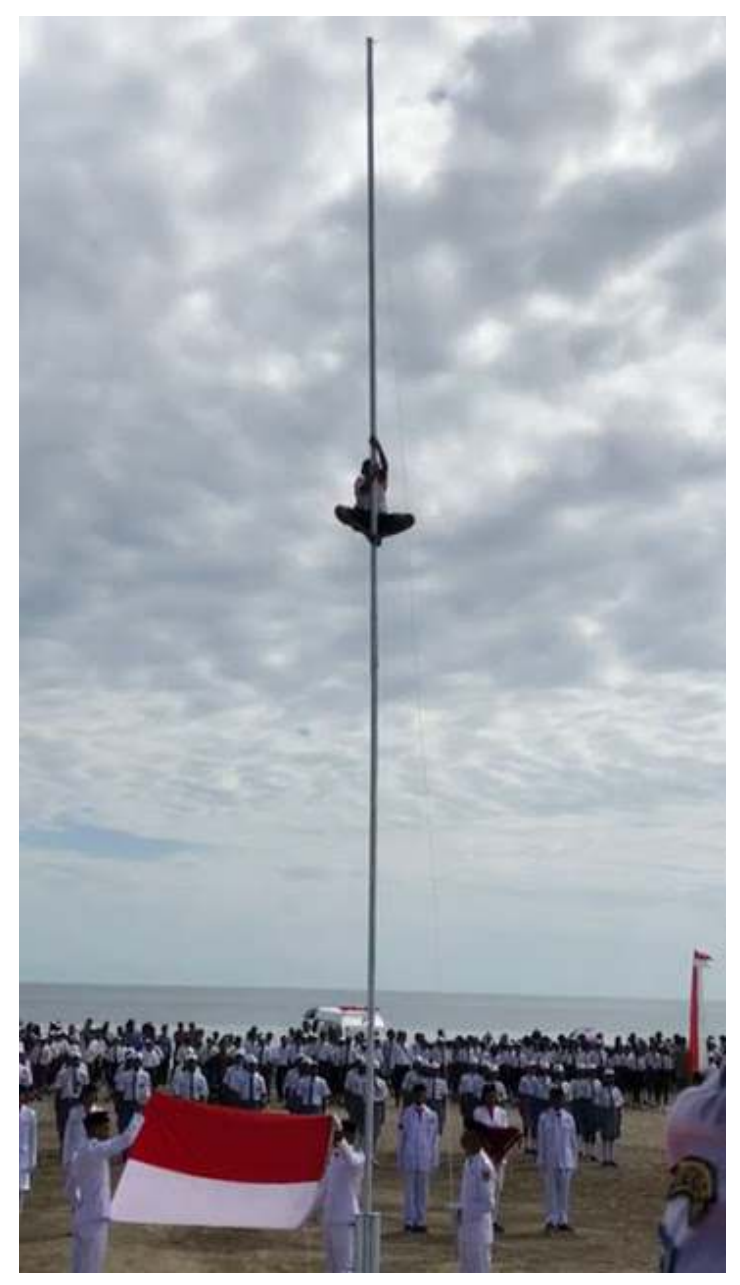

Fig. 2. The picture of the true story of Johannes Adekalla

The scene at 01:54 was inspired by a true story carried out by Joni or Johannes Adekalla when he tried to climb a flagpole because of the red and white flag rope that broke up at his school when the 73rd Indonesian Independence Day ceremony took place. Besides, there is also a scene depicting a teacher who is giving the spirit and values of nationalism or the love of the motherland to elementary school students in this film, namely at 00:23 - 00:30. In the scene, the teacher invites and leads the students to carry out the spirit of nationalism by saying. "Saya orang Indonesia, saya Pancasila, NKRI harga mati, Merah Putih selalu di hati". 


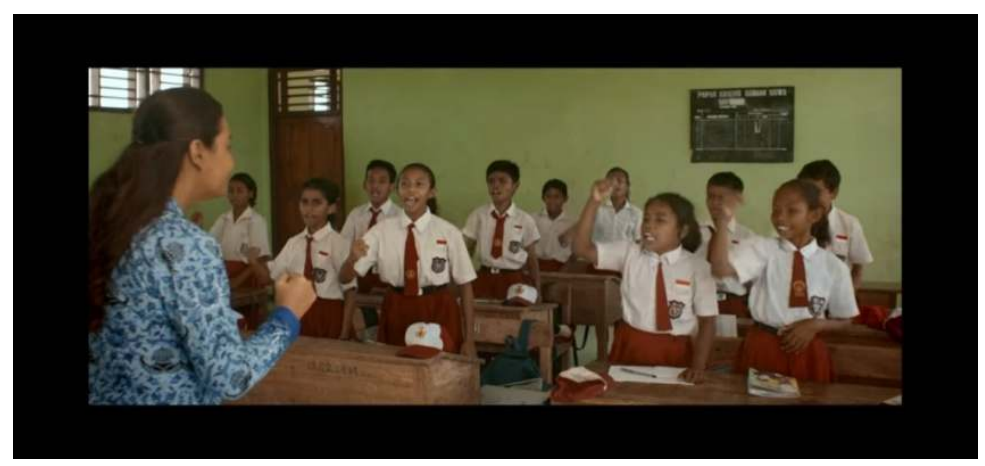

Fig. 3. Cut scenes at 00:29 in the film "Rumah Merah Putih"

As at minute 00:34 it was described how the spirit of the Atambua residents who were still enthusiastic and busy following the Red and White flag ceremony with solemnity and wisdom and at 02:04 was spoken by Oscar words that reflect the spirit of nationalism embedded in him, "Saya Indonesia" or "I am Indonesia" while in tears.

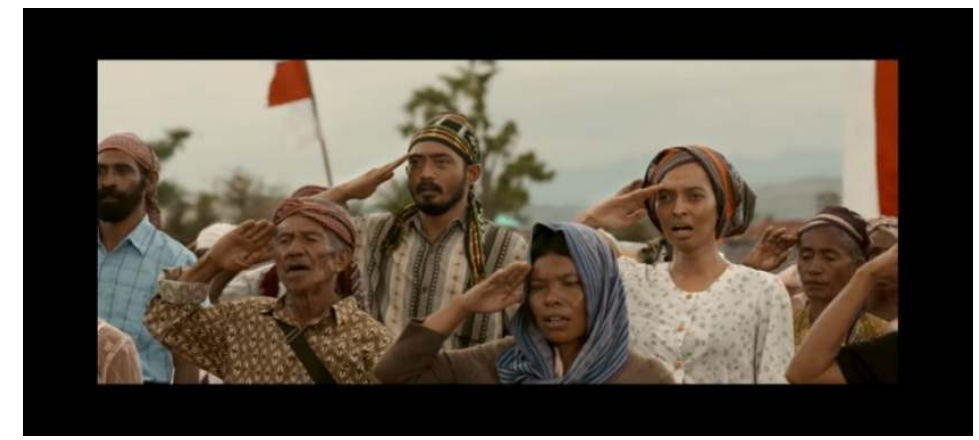

Fig. 5. Cut scenes at 02:04 in the film "Rumah Merah Putih",

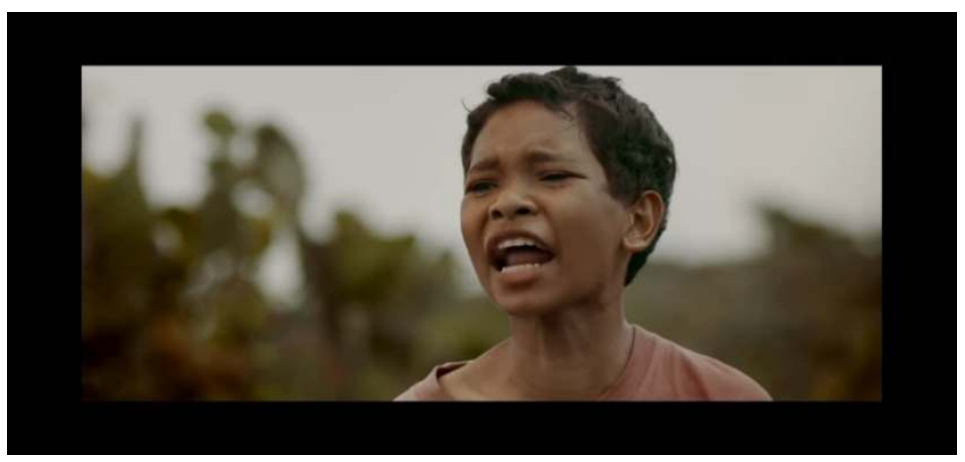

Fig. 6. Cut scenes at 00:34 in the film "Rumah Merah Putih" 


\section{Rumah Merah Putih as a home for unification within Indonesian society}

Based on the fragments of the scenes that have been described and explained in chapter VI about the text and context contained in the film "Rumah Merah Putih", the representation of the scenes will be analyzed or examined in depth in this part of the chapter. Scenes taken, for example to be examined in this article are scenes that are portrayed visually or verbally by the characters in this film to clearly and clearly convey the message or meaning that the portraits of people in the border areas, one of them in Atambua, Belu it is very thick towards a sense of nationalism and love for Indonesia as their homeland.

The film, which takes the title "Rumah Merah Putih" also intends to convey meaning in writing that Indonesia is a home for anyone without knowing the ethnicity, race, or origin of any region in Indonesia because Indonesian citizens are Indonesian people who are united among the diversity very diverse. In addition, the scene at minute 00:34 attempted to convey a message to the wider Indonesian community from Sabang to Merauke to re-live the meaning of the Red and White flag ceremony which was supposed to be carried out by Indonesians not only while still in elementary school, but it should also be carried out until reaching the age of adulthood, so that the spirit of nationalism and unity of the Indonesian nation which is harmonious in Indonesia or it called Negara Kesatuan Republik Indonesia (NKRI) is embedded. In addition, this film also conveys the message of the need for the role of teachers and the community to instill the spirit of nationalism in the next generation of the nation as a form of deradicalism to safeguard Indonesian unity amid shocks and dynamics of values or understandings that seek to undermine Indonesia's unity that has been maintained and lasted for 73 years.

In addition, based on the theory of Sven Windhal and Denis McQuail's and pieces of scene evidence from the official trailer of the film "Rumah Merah Putih" released in 2019, it shows that this film is not only a medium that provides film viewing to its viewers, but rather interpreting its role to convey meaning to its audience like the meaning of deradicalism amid the onslaught of the issue of radicalism. The meaning conveyed from the scenes pieces in the film also relates to individual attributes or preference patterns formed by the family, social class environment, education, and 'cultural capital' within each individual or referred to as 'Cultural Taste' [5]. The 'Cultural Taste' will refer to an organized set of cultural artifacts that are not united by the aesthetics of any party or by the preference of class or social groups which in the context of this film refers to the Indonesian people who up to now live in diversity within Unity of the Republic of Indonesia In addition, referring to the function of films that work with a democratic system to allow freedom of expression according to Bourdieu, working to convey the emotions of nationalism and the unity of the Indonesian nation that is being confronted with the problems of radicalism movements. 


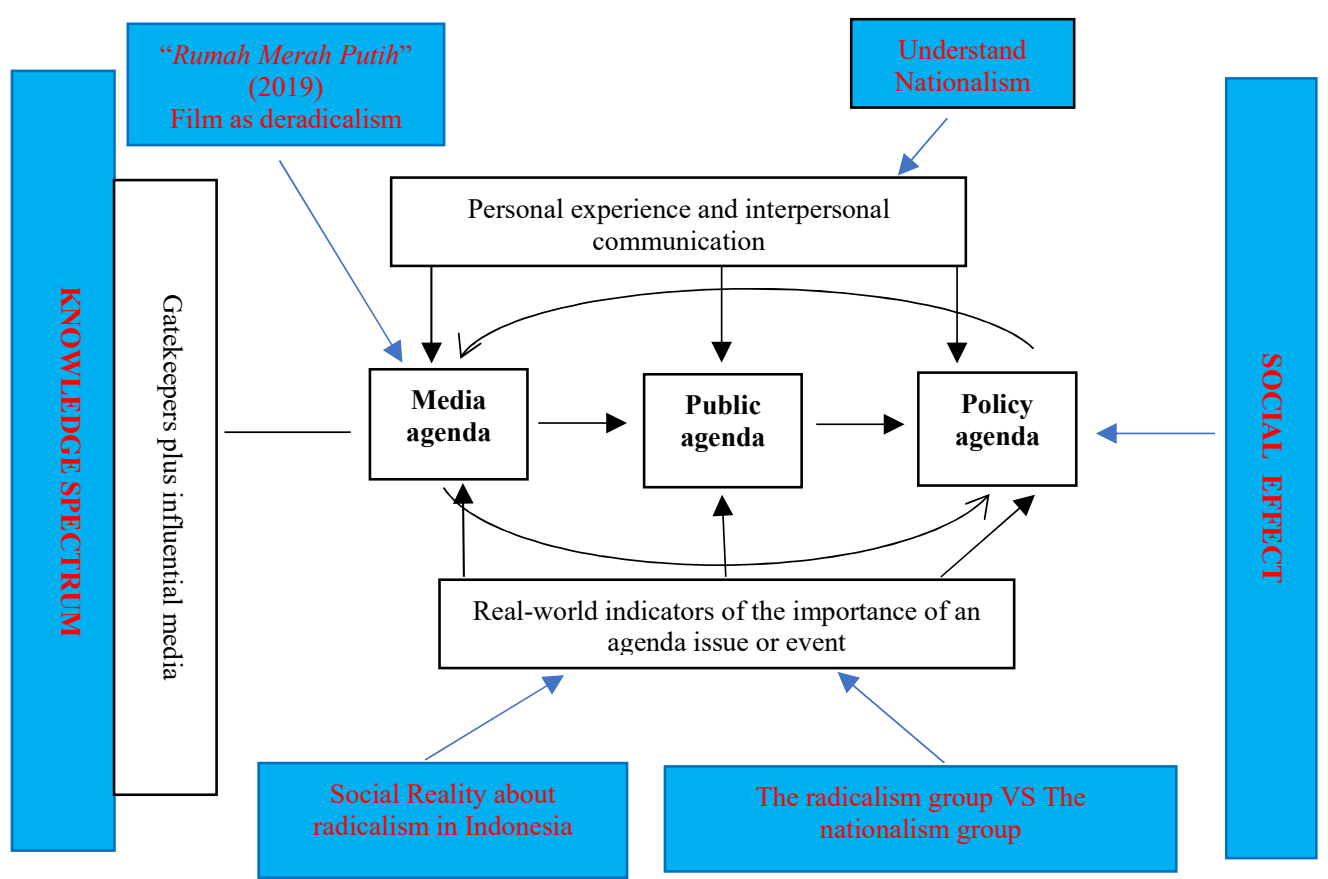

Fig. 6 Rogers and Dearing's model of agenda-setting (1987)

\section{Conclusion}

That the film entitled "Rumah Merah Putih" (2019) is a film that acts as a medium of the results of popular culture in Indonesia to convey a meaning or message to the audience or audience. The message or meaning that is attempted to be conveyed from the scenes analyzed in the review of this article is to re-grow the spirit of unity and nationalism within each Indonesian society. Also, this film acts as a form of media to convey the issue of deradicalism from a portrait of the reality of community life on the Indonesian border.

Acknowledgments. Hendra Kaprisma is a member of the Department of Literature Faculty of Humanities, Universitas Indonesia. Every day he assists and supports lectures at a bachelor's degree in Russian Studies Program and graduates degree in Literature Studies Program of Faculty of Humanities UI. He completed his undergraduate education in 2008 at the Russian Studies Program of Faculty of Humanities UI. Later, he continued his doctoral studies in Literature Studies of Faculty of Humanities UI and graduated in 2015. In 2011-2012 he attended the Sandwich Ph.D. program at Saint-Petersburg State University.

\section{References}

[1] A. Heryanto, Popular Culture in Indonesia: Fluid Identities in Post-authoritarian Politics. Abingdon: Routledge., 2008. 
[2] F. Stern, Screening Politics: Cinema and Intervention. Washington: Georgetown University Press., 2000.

[3] R. V. Hadiz, Islamic Populism In Indonesia and The Middle East. Cambridge: Cambridge University Press, 2016.

[4] A. Asrori, Radikalisme di Indonesia: Antara Historisitas dan Antropisitas. Lampung: IAIN Raden Intan., 2015.

[5] S. Windahl, Communication Models: For the Study of Mass Communication. New York: Routledge, 2013.

[6] P. Bourdieu, On Television. New York: The New Press., 1996.

[7] P. Bourdieu, Key Sociologists. Milton Keynes: The Open University., 1992. 